\title{
PELAKSANAAN PEMBELAJARAN BRAILLE PADA SISWA TUNANETRA DI KELAS DI TAMAN KANAK-KANAK SLB A YPAB SURABAYA
}

\author{
Lutfi Isni Badiah ${ }^{1}$, Muhammad Nurrohman Jauhari ${ }^{2}$, Sambira Mambela ${ }^{3}$ \\ Program Studi Pendidikan Khusus \\ Universitas PGRI Adi Buana Surabaya \\ lutfiisnibadiah@gmail.com ${ }^{1}$ mnjauhari@unipasby.ac.id ${ }^{2}$, sam.mambela@gmail.com ${ }^{3}$
}

\begin{abstract}
Abstrak
Tujuan dari penelitian ini adalah untuk mendeskripsikan pelaksanaan pembelajaran braille untuk siswa tunanetra pada kelas taman kanak-kanak pada ditinjau dari aspek pelaksanaan, metode pembelajaran yang digunakan, dan hambatan yang dialami. Dalam penelitian ini subjek penelitian terdiri dari: guru kelas; siswa tunanetra Jenis penelitian ini merupakan penelitian lapangan (field research). Teknik Pengumpulan data melalui pengamatan, wawancara, dokumentasi. Teknik analisis data dalam penelitian ini dilakukan dengan mengumpulkan dan menelaah seluruh data yang diperoleh kemudian mereduksi yakni dengan pemilihan, penyederhanaan, dan pemusatan perhatian pada hal yang menguatkan data yang diperoleh di lapangan. Kemudian dilakukan penyajian dengan cara mendeskripsikan dalam bentuk uraian/kalimat yang mudah dimengerti. Langkah terakhir adalah dengan melakukan verifikasi, penyajian data dan pengambilan kesimpulan. Dari hasil penelitian, diperoleh kesimpulan bahwa: (1) pelaksanaan pembelajaran braille di kelas taman kanakkanak selalu diawali dengan latihan pengembangan motoric halus dan latihan dria taktual. Latihan pengembangan motorik dan latihan dria taktual ini bertujuan untuk melatih kesiapan anak dalam membaca dan menulis braille, (2) metode pembelajaran yang digunakan oleh guru ketika mengajarkan membaca dan menulis permulaan menggunakan berbagai macam metode, diantaranya metode ceramah, metrode drill, metode demonstrasi dan metode tanya jawab. Dalam memilih metode pembelajaran, guru seringkali menggunakan metode yang bervariasi, dengan menggunakan ketepatan penggunaan metode pembelajaran dengan karakteristik siswa tunanetra, (3) Hambatan yang biasa ditemui dalam pembelajaran membaca dan menulis braille permulaan ini adalah banyaknya materi yang harus disampaikan sedangkan alokasi waktu pembelajaran braille yang kurang, dan media pembelajaran braille yang tersedia kurang lengkap serta kurang bervariasi.
\end{abstract}

Kata kunci: Braille, Anak Tunanetra, Membaca.

\section{PENDAHULUAN}

Pembelajaran merupakan proses komunikasi dua arah antara pengajar dan peserta didik. Kegiatan mengajar dilakukan oleh guru sebagai pengajar sedangkan kegiatan belajar dilakukan 
oleh siswa. Pembelajaran menurut (Sagala, 2011) merupakan kegiatan untuk membantu peserta didik dalam memperoleh pengetahuan, keterampilan atau nilai yang baru. Terdapat aspek penting yang harus dikuasai oleh seorang guru dalam kaitannya dengan proses pembelajaran, yakni kesiapan guru mengenal karakteristik siswanya. Guru yang telah mengetahui bagaimana karakteristik siswanya ketika proses pembelajaran berlangsung, merupakan modal utama dan menjadi indikator suksesnya pelaksanaan pembelajaran. Pengetahuan guru mengenai karakteristik peserta didik termasuk kemampuan dasar yang dimiliki oleh siswa, latar belakang akademisnya, latar belakang sosial ekonominya, termasuk juga kemampuan kebutuhan khususnya (mengalami kebutuhan khusus atau tidak).

Indera penglihatan asalah salah satu indera manusia sebagai saluran masuknya informasi selain indera pendengaran, indera pengecap, indera pembau, dan indera perabaan. Hampir $80 \%$ informasi yang diperoleh oleh seseorang, didapat dari indera penglihatan (Djuang, 2005). Seseorang yang kehilangan kemampuan penglihatan, sama halnya dengan kehilangan informasi yang bersifat visual. Sebagai akibat dari kehilangan penglihatan ini, maka seseorang yang mengalami kelainan penglihatan atau yang biasa disebut dengan orang tunanetra akan kehilangan informasi yang sifatnya visual.

Kata tunanetra berasal dari kata tuna yang bermakna rusak, dan netra yang bermakna mata. Jadi tunanetra mempunyai makna mata yang rusak, atau rusak penglihatan (Djuang, 2005). Pembelajaran untuk anak tunanetra terdapat beberapa aspek yang perlu diperhatikan, yakni (1) lingkungan fisik, (2) prosedur pembelajaran, dan (3) isi dan bahan pembelajaran. Prinsip pembelajaran untuk siswa tunanetra meliputi: pengalaman kongkrit, pengalaman yang utuh, dan belajar dengan melakukan. Untuk mengakomodasi kebutuhan belajarnya, siswa tunanetra membutuhkan pembelajaran kompensatoris, diantaranya membaca dan menulis Braille, keterampilan orientasi dan mobilitas (OM), keterampilan penggunaan indera selain penglihatan, serta keterampilan aktivitas fisik. Keterampilan membaca dan menulis Braille merupakan modal utama bagi siswa tunanetra untuk menunjang proses akademik di tingkat selanjutnya (Jabar, 2017).

Berdasarkan hasil dari observasi awal pada bulan Oktober 2018 di SLB A YPAB Surabaya, peneliti menemukan siswa tunanetra yang masih kurang atau adanya keterlambatan dalam kemampuan membaca dan menulis Braille. Hal ini dikarenakan bahwa 
setiap kemampuan siswa tunanetra bervariasi akibat dari kemampuan tunanetra itu sendiri dan tidak adanya latihan membaca dan menulis Braille secara khusus. Latihan membaca dan menulis Braille di SLB A YPAB Surabaya hanya menjadi bagian dari mata pelajaran Bahasa Indonesia dan tidak ada jam pelajaran khusus mengenai latihan membaca dan menulis Braille. Latihan membaca dan menulis Braille yang tidak dijadikan sebagai mata pelajaran secara tidak langsung memberikan dampak bagi pembelajaran Braille yang mungkin tidak tersampaikan secara menyeluruh pada siswa tunanetra.

Keterampilan membaca dan menulis braille siswa tunanetra tidak secara otomatis didapat, melainkan diperoleh dari latihan yang intens. Semakin dilatih dari sejak dini, maka keterampilan siswa tunanerta dalam membaca dan menulis braille akan semakin terampil. Karenanya, latihan keterampilan membaca dan menulis braille diajarkan sejak bangku taman kanak-kanak. Termasuk di SLB A YPAB Surabaya, di kelas taman kanakkanak sudah diajarkan keterampilan membaca dan menulis braille permulaan.

Berdasarkan uraian di atas, maka peneliti ingin mengetahui lebih lanjut tentang pembelajaran membaca dan menulis Braille permulaan bagi siswa tunanetra di taman kanak-kanak SLB A
YPAB Surabaya. Sehingga dalam penelitian ini penulis mengambil judul "Studi Deskriptif Pembelajaran Braille Pada Siswa Tunanetra Taman KanakKanak di SLB A YPAB Surabaya."

Dari uraian latar belakang di atas, peneliti menguraikan rumusan pertanyaan penelitian, yaitu “Bagaimana pelaksanaan pembelajaran braille untuk siswa tunanetra pada kelas taman kanak-kanak ditinjau pada aspek pelaksanaan, metode pembelajaran dan hambatan yang dialami?"

\section{METODOLOGI PENELITIAN}

Penelitian diadakan di SLB A YPAB Surabaya. Sedangkan subyek penelitian ini adalah guru kelas dan siswa tunanetra kelas taman kanakkanak. Jenis penelitian ini merupakan penelitian lapangan (field research) yakni penelitian yang proses pengumpulan datanya dilaksanakan di lapangan. Penelitian ini bersifat kualitatif dan deskriptif.. Untuk teknik pengumpulan datanya menggunakan teknik observasi, wawancara, dan dokumentasi. Sedangkan untuk teknik analisis data dilakukan dengan cara : 1) mengumpulkan dan menelaah seluruh data yang diperoleh, 2) mereduksi data (pemilihan, penyederhanaan, dan pemusatan perhatian pada hal yang menguatkan data), 3) penyajian data dengan mendeskripsikan dalam bentuk uraian/kalimat, 4) dan langkah 
terakhir adalah dengan melakukan verifikasi, penyajian data dan pengambilan kesimpulan.

\section{HASIL DAN PEMBAHASAN}

\section{Pelaksanaan Pembelajaran}

Membaca dan Menulis Braille Permulaan

Pembelajaran braille di kelas taman kanak-kanak selalu diawali dengan latihan dria tactual dan motoric halus. Latihan dria tactual dan motorik halus ini bertujuan untuk melatih kesiapan anak dalam membaca dan menulis braille. Diantaranya seperti meraba berbagai jenis permukaan (mulai dari permukaan halus sampai kasar), meraba berbagai macam bentuk garis yang timbul, dan latihan meremas benda lunak. Hal ini dilakukan untuk melatih dria taktual anak tunanetra agar peka dan kuat (Rudiyati, 2009). Latihan dria tactual dan motorik halus pada anak tunanetra ini membutuhkan waktu yang cukup lama, dan membutuhkan kesabaran, ketelatenan. Sebagaimana yang disampaikan oleh (Rudiyati, 2010), bahwa kepekaan dria taktual anak tunanetra harus selalu dilatih karena merupakan tuntutan dalam memiliki kecakapan membaca dan menulis Braille. Sedangkan kepekaan sensoris anak tunanetra diperoleh dari adanya latihan dan pembelajaran yang berulang bagi anak.

Dalam melakukan latihan kepekaan dria taktual untuk anak tunanetra juga diperlukan kreatifitas guru. Bahkan tidak jarang guru di SLB A YPAB menggunakan benda yang gampang ditemukan, seperti buble wrap, biji-bijian, pasir dan amplas. Penggunaan buble wrap ini selain mudah ditemukan, murah, dapat digunakan untuk melatih sensori anak tunanetra dengan diminta menekan gelembung pada buble wrap.

\section{Metode Pembelajaran Menbaca dan Menulis Braille Permulaan}

Untuk meningkatkan kemampuan anak tunanetra dalam membaca dan menulis braille, perlu adanya stimulasi dari guru, pemilihan strategi dan media yang sesuai sehingga bisa mengakomodasi kebutuhan pembelajaran siswa tunanetra (Sattria, 2012). Guru atau pengajar di kelas Taman Kanak-Kanak SLB A YPAB Surabaya ketika mengajarkan membaca dan menulis permulaan kepada anak tunanetra menggunakan berbagai macam metode, diantaranya metode ceramah, metrode drill, metode demonstrasi dan metode tanya jawab. Dalam memilih metode pembelajaran, guru seringkali menggunakan metode yang bervariasi, dengan menggunakan ketepatan penggunaan metode pembelajaran dengan karakteristikm siswa tunanetra. Siswa tunanetra di kelas TK SLB A YPAB Surabaya ini tidak hanya terdiri dari anak dengan gangguan penglihatan semata, namun juga ada 
anak tunanetra yang disertai dengan hambatan lain, yang biasa disebut dengan MDVI (multiple disability with visual impairment). Mengajar membaca dan menulis braille permulaan untuk anak MDVI membutuhkan tenaga dan strategi khusus.

Saat kegiatan pelaksanaan menulis permulaan braille ini, guru tidak langsung menggunakan kertas yang tebal, sebagaimana kertas yang ideal untuk menulis braille. Hal ini bertujuan agar anak tidak mudah lelah ketika menulis menggunakan stylus di kertas. Apabila anak langsung diberikan kertas yang tebal, maka anak akan mudah cepat lelah menulis dan pada akhirnya tidak mau belajar menulis kembali. Menurut Bu Atin ini, anak-anak di kelas rata-rata aktif dan antusias dalam mengikuti kegiatan membaca dan menulis braille. Meskipun untuk siswa MDVI selalu harus dibawah pantauan guru kelas secara intens dan diberi dorongan terus untuk mau ikut kegiatan dan menulis braille. Sebagaimana seperti yang disampaikan oleh ..., bahwa untuk membiasakan siswa tunanetra membaca dan menulis braille, maka perlu latihan yang terus menerus (Rudiyati, 2010)

Untuk kegiatan membaca dan menulis permulaan, guru menggunakan metode demonstrasi, yakni memberi contoh kepada anak tunanetra cara memasangkan dan melepaskan kertas pada reglet, serta cara memegang stylus yang benar. Kemudian meminta anak untuk mempraktekkannya. Selanjutnya, mencontohkan cara menusuk stylus ke dalam kotak reglet. Guru kemudian meminta anak untuk praktek menusuk reglet ke sembarang titik asalkan masih tetap pada kotak reglet. Hal ini untuk melatih dan mengenalkan anak bahwa huruf braille terdiri dari 6 titik untuk setiap kotak reglet. Setelah anak dinilai mampu menusuk ke dalam kotak reglet dengan tepat, anak diminta menusuk ke dalam titik yang diinstruksikan oleh guru. Untuk menulis braille, anak diajari untuk menulis dari kanan ke kiri, dengan prinsip pencerminan. Karena untuk membaca, tulisan braille yang timbul yang akan dibaca. Guru harus selalu mendampingi, memberikan latihan drill dan memberi kesempatan anak untuk bertanya jika merasa belum paham.

Untuk membaca braille permulaan, guru menggunakan media paku payung yang ditancapkan ke lempengan kayu dan media kartu braille. Pada awal membaca permulaan, siswa tunanetra dikenalkan dlu mengenai konfigurasi titik braille yang terdiri dari 6 titik. Setelah anak tunanetra mampu membedakan konfigurasi titik-titik braille, maka selanjutnya anak dikenalkan dengaan konfigurasi huruf 
dan abjad braille. Untuk membaca braille, guru menggunakan pendekatan mengajar individual dengan memperhatikan karakteristik anak masing-masing.

\section{Hambatan yang dialami}

Hambatan yang biasa ditemui dalam pembelajaran membaca dan menulis braille permulaan ini adalah banyaknya materi yang harus disampaikan sedangkan alokasi waktu pembelajaran braille yang kurang, dan media pembelajaran braille yang tersedia kurang lengkap serta kurang bervariasi. Kesulitan lainnya yang sering ditemui dalam kegiatan pembelajaran braille di kelas taman kanak-kanak SLB A YPAB Surabaya adalah kesulitan membedakan hurufhuruf, terutama huruf yang mirip. Seperti contohnya huruf yaitu : pada huruf "i" dan "e", "b" dan "c", serta " $r$ " dan " $w$ ". Selain itu, siswa tunanetra juga secara tidak sadar, menumpuk huruf dalam satu kotak abjad yang sama. Hal ini disebabkan karena pada umumnya siswa tunanetra belum bisa mengoperasikan reglet dengan baik. Oleh karena itu, guru sering memantau dan membantu siswa tunanetra. Media yang digunakan, dirasakan kurang bervariasi. Media pembelajaran braille yang bervariasi dapat memberikan manfaat yakni dapat memperlancar interaksi antara guru dan siswa, agar siswa dapat belajar dengan maksimal (Widiyaningtyas \& Astuti, 2011).
Sehingga untuk mengakalinya, guru harus berkreatifitas sendiri mencari alat dan bahan yang bisa ditemukan di sekitar anak, yang bisa digunakan untuk melatih kepekaan dria visual anak tunanetra.

\section{SIMPULAN}

Pembelajaran braille di kelas taman kanak-kanak selalu diawali dengan latihan pengembangan motorik. Latihan pengembangan motorik ini bertujuan untuk melatih kesiapan anak dalam membaca dan menulis braille.

Guru atau pengajar di kelas Taman Kanak-Kanak SLB A YPAB Surabaya ketika mengajarkan membaca dan menulis permulaan kepada anak tunanetra menggunakan berbagai macam metode, diantaranya metode ceramah, metrode drill, metode demonstrasi dan metode tanya jawab. Dalam memilih metode pembelajaran, guru seringkali menggunakan metode yang bervariasi, dengan menggunakan ketepatan penggunaan metode pembelajaran dengan karakteristikm siswa tunanetra.

Hambatan yang biasa ditemui dalam pembelajaran membaca dan menulis braille permulaan ini adalah banyaknya materi yang harus disampaikan sedangkan alokasi waktu pembelajaran braille yang kurang, dan media pembelajaran braille yang tersedia kurang lengkap serta kurang bervariasi. 


\section{DAFTAR PUSTAKA}

Djuang, S. (2005). Potensi Anak Berkelainan Penglihatan.

Departemen Pendidikan Nasional.

Jabar, P. N. (2017). Media Braille Pada Pembelajaran Piano Untuk Siswa Tunanetra di SMPLB-A (YPAB) Surabaya. Jurnal Pendidikan Sendratasik UNESA, $6(1)$.

Rudiyati, S. (2009). Latihan Kepekaan Dria Non Visual Bagi Anak Tunanetra Buta. Jurnal Pendidikan Khusus, 5(2).

Rudiyati, S. (2010). Pembelajaran Membaca dan Menulis Braille Permulaan Pada Anak Tunanetra. Jassi Anakku, 9(1), 5775.
Sagala, S. (2011). Konsep dan Makna Pembelajaran. Alphabeta.

Sattria, R. (2012). Meningkatkan Kemampuan Mengenal Huruf Braille Melalui Media Kartu Huruf Anak Tunanetra. 1(September), 320-331.

Widiyaningtyas, T., \& Astuti, L. D. (2011). Aplikasi Media Pembelajaran Pengenalam Huruf Braille Berbasis Komputer. Seminar Electrical, Informatics and Education, A3-61A3-64.

http://elektro.um.ac.id/ceie/2011 /assets/paper/National/Educatio n/A3-9

TRIYANNA_WIDIYANINGTY AS - APLIKASI MEDIA PEMBELAJARAN.pdf 